\title{
Candidate Surveys on Program Evaluation: Examining Instrument Reliability, Validity and Program Effectiveness
}

\author{
Ruchi Bhatnagar ${ }^{1, *}$, Jihye Kim², Joyce E. Many ${ }^{1}$ \\ ${ }^{1}$ Dean's office, Georgia State University, Atlanta, Ga, USA \\ ${ }^{2}$ University System of Georgia, Atlanta, Ga, USA \\ *Corresponding author: rbhatnagar@gsu.edu
}

Received May 30, 2014; Revised August 08, 2014; Accepted August 12, 2014

\begin{abstract}
This self-study conducted by an urban college of education examined the effectiveness of its teacher education programs in emphasizing its social justice conceptual framework, as perceived by its teacher candidates. The study included development of an electronic survey based on the ten learning outcomes of the unit's conceptual framework, and testing the internal consistency reliability and the construct validity of the survey items. The survey was administered to teacher education candidates who rated their program's effectiveness in fulfilling the unit's vision of preparing educators that are informed and empowered, committed, and engaged with students and their communities. We analyzed data from teacher candidates at mid or end points in their programs over two academic years. Our results indicated that the survey was a valid and reliable instrument for collecting candidates' feedback on program improvement. Candidates' feedback showed differences among the three programs in their emphasis on the conceptual framework. Additionally, there were some learning outcomes that were rated low in both years by the candidates, implying that some outcomes are being more successfully emphasized in the programs than others. These results were important feedback for the teacher education unit to move along the path of self-reflection and continuous improvement.
\end{abstract}

Keywords: teacher education effectiveness, candidate surveys, validity, reliability

Cite This Article: Ruchi Bhatnagar, Jihye Kim, and Joyce E. Many, "Candidate Surveys on Program Evaluation: Examining Instrument Reliability, Validity and Program Effectiveness.” American Journal of Educational Research, vol. 2, no. 8 (2014): 683-690. doi: 10.12691/education-2-8-18.

\section{Introduction}

In this era of accountability it is imperative for teacher education programs to reflect on their intended design and content, and evaluate if their graduates have mastered the key elements of the program, that will likely impact their effectiveness classrooms as future teachers (Diez, 2010). Numerous standards and expectations arising from policy mandates, accreditation process such as the National Council for Accreditation of Teacher Education (NCATE), and state regulations are a part of the design and functioning of teacher education programs. Such standards and policy mandates require programs to provide databased evidence that their graduates have gained mastery of the relevant learning outcomes or face high-stakes repercussions.

However, evaluating graduates' learning of these standards can become complicated if the expectations and standards are not made explicit in a meaningful way through course foci, experiences, and assessments (Delandshere \& Petrosky, 2004; Diez; Peck, Gallucci, \& Sloan, 2010). Listing the standards or learning outcomes on syllabi or in assignments does not necessarily translate into a mastery of these elements unless, sufficient time is spent unpacking these standards, ample opportunities are provided to the candidates to apply and integrate these standards in their practices, and repeated references are made to these outcomes across course work and practica (Bhatnagar, 2011; Cibulka, 2009; Diez). Thus, along with assessing candidates in light of specific standards, teacher educators must also carefully consider the extent to which programs effectively emphasize standards in a way that enables candidates to develop a deep understanding of the designated learning outcomes.

As part of the accreditation process for NCATE and accountability towards state standards, teacher education institutions are often asked to develop a conceptual framework which reflects a collective vision for the unit in its process of preparing educators (NCATE, 2008). A key aspect of the conceptual framework is a set of clear learning outcomes that its candidates will be assessed on in order to be recommended for certification (Diez, 2010; NCATE). An institution develops a conceptual framework which characterizes the unique vision, mission, and goals which will guide their preparation of educational professional. The purpose of this study was to examine the perspectives of candidates across the diverse teacher preparation programs in one institution to understand the 
degree to which they felt the learning outcomes identified by their institution were salient as they progressed through their programs.

The context of this study is a professional education unit located within an urban research university. NCATE accredits the unit while the state reviews and approves the individual teacher education programs. The educator preparation unit consists of faculty from both the college of education and the college of arts and sciences. The faculty work closely with the diverse metropolitan schools in their area. In recent years, the professional education faculty revised their conceptual framework to more clearly articulate the importance of preparing educators for urban contexts who work for social justice and equity. The faculty crafted a mission focused on preparing educators "who are: (a) informed by research, knowledge and reflective practice and empowered to serve as change agents; (b) committed to and respectful of all learners; and (c ) engaged with learners, their families, schools, and local and global communities" (Author institutional document). Each of these elements characterized the guiding principles upon which the conceptual framework was structured. Ten learning outcomes were crafted in concert with these principles and in light of national standards for the preparation of teachers (INTASC, 2003).

Table 1. Conceptual Framework Learning Outcomes

\begin{tabular}{|c|c|}
\hline & Informed \& Empowered \\
\hline 1 & $\begin{array}{l}\text { Our candidates use their knowledge of child, adolescent, and adult } \\
\text { development and theories of learning to design meaningful } \\
\text { educational opportunities for all learners. }\end{array}$ \\
\hline 2 & $\begin{array}{l}\text { Our candidates possess and use research-based, discipline-specific } \\
\text { knowledge and pedagogy to facilitate learning for all. }\end{array}$ \\
\hline 3 & $\begin{array}{l}\text { Our candidates reflect critically upon data as part of a recursive } \\
\text { process when planning, implementing and assessing teaching, } \\
\text { learning, and development. }\end{array}$ \\
\hline \multirow[t]{2}{*}{4} & $\begin{array}{l}\text { Our candidates critically analyze educational policies and/or } \\
\text { practices that affect learners in metropolitan contexts. }\end{array}$ \\
\hline & Committed \\
\hline 5 & $\begin{array}{l}\text { Our candidates know and respect individual differences, establish } \\
\text { productive and ethical relationships with students, and modify the } \\
\text { learning environment to positively impact student learning. }\end{array}$ \\
\hline 6 & $\begin{array}{l}\text { Our candidates create engaging learning communities where the } \\
\text { diverse perspectives, opinions, and beliefs of others are } \\
\text { acknowledged and respected. }\end{array}$ \\
\hline \multirow[t]{2}{*}{7} & $\begin{array}{l}\text { Our candidates commit to continuing personal and professional } \\
\text { development. }\end{array}$ \\
\hline & Engaged \\
\hline 8 & $\begin{array}{l}\text { Our candidates use knowledge of students' cultures, experiences, } \\
\text { and communities to create and sustain culturally responsive } \\
\text { classrooms and schools. }\end{array}$ \\
\hline 9 & $\begin{array}{l}\text { Our candidates coordinate time, space, activities, technology and } \\
\text { other resources to provide active and equitable engagement of } \\
\text { diverse learners in real world experiences. }\end{array}$ \\
\hline 10 & $\begin{array}{l}\text { Our candidates implement appropriate communication techniques } \\
\text { to provide for learner interaction within local and global } \\
\text { communities. }\end{array}$ \\
\hline
\end{tabular}

In the first guiding principle, the faculty emphasized the need to prepare candidates informed by research, knowledge and reflective practice. Faculty were committed to providing candidates opportunities to critically examine theoretical and applied inquiry, their own practices, and the practices of others to make wellreasoned, data-based decisions about teaching, learning, and development (Cochran-Smith 2004; Darling-
Hammond \& Bransford, 2005; Feiman-Nemser, 2001). Faculty also drew on scholarship in the field to consider how to prepare teachers to be empowered as change agents in the pursuit of social justice and equity (CochranSmith; Fairbanks, et al. 2010; King, 2000; 2006). The faculty designed the first four learning outcomes in Table 1 in light of the first guiding principle.

The second guiding principle developed by the faculty emphasized that candidates need to be respectful of all learners and committed to the belief that all people can learn (Delpit, 1995; Dewey, 1933; Gay, 2010). Faculty underscored that teachers should be ethical, knowledgeable, and caring advocates for students and their families (Noddings, 2002; Pianta 1999). The three learning outcomes associated with this principle reflect this emphasis on developing learning communities for the growth and well-being of all learners as well as the continued personal and professional development of the teacher candidates.

In the third guiding principle of the conceptual framework, the faculty stressed their beliefs that candidates are to be engaged with learners, their families, schools, and local and global communities (Lieberman \& Mace, 2010). Faculty recognized the potential and use of technology to enhance learning and communication (Landow, 2006; Wysocki, 2004) and noted that technology is a vital cultural tool with socio-cultural implications. The final three learning outcomes in Table 1 are associated with this principle. The integration of these conceptual framework learning outcomes within program design and delivery was important to fulfill this institution's aim of preparing educators to work in urban settings.

\section{Background for the Study}

Accountability driven standards are an important part of the political landscape that teacher education colleges operate in. A blue ribbon panel assembled by NCATE called for turning the education of teachers upside-down and emphasized the need to build excellent teacher preparation programs throughout the nation (NCATE, 2010). The comprehensive reform that policy makers and researcher alike have suggested for teacher education, has included collecting data within programs based on standards which would contribute to the evidence of program quality.

Many teacher education institutions routinely gather information for continuous improvement and accountability (Cochran-Smith \& The Boston College Evidence Team, 2009; Wineburg, 2006). Teacher educators have advocated the use of self-studies as an effective tool to examine the consistency between practice and beliefs and to engage in critical reflection, and as a way of seeking alternative views to evaluate the program (Berry, 2004; Loughran, 2006). Adding the insight of teacher candidates and graduates to the research on selfpractices offers perspectives that are invaluable in the pursuit of continuous improvement (Zeichner, 2005). Previous studies have shown that a teacher preparation program's candidates' perception of their program can be very different from the intended design by the program faculty (Korthagen, Loughran \& Russell, 2006). 
Additionally, perceptions of candidates enrolled in different teacher preparation programs can vary considerably, even when the programs are offered within the same institution. Candidates' ratings of the program are also impacted by how far along they are in the program (Cochran-Smith et al., 2009).

Researchers focusing on student teachers' perspectives have explored several issues related to program design such as: (a) opportunities offered by the program to apply theory into practice prior to graduation, (b) the usefulness of particular courses in content areas, pedagogy and methods, (c) coherence among the various aspects of preparation, and (d) feedback about the program elements that worked well or elements they would recommend changing (Berry, 2004; Grossman, Hammerness, McDonald \& Ronfeldt, 2008; Korthagen, et al., 2006). Field experiences and student teaching usually rank as the most useful aspects of teacher education from candidates' perspectives (Wilson, Floden, \& Ferrini-Mundy, 2001). Thus, student perspectives can be helpful in understanding the weak links within teacher preparation and bolstering the aspects that are already strong.

Over the years, there has been an increasing emphasis on establishing the reliability and validity of various measures and instruments used in collecting data on program effectiveness (Goe, Bell, \& Little, 2008; Plecki, Elfers \& Nakamura, 2012). Teacher education as a field has been critiqued for its lack of attention to validity and reliability issues in evaluation research (Grossman et al., 2008). Validity is the most fundamental consideration in assuring the quality of any instrument and is therefore, vital to investigate (Millet, Stickler, Payne \& Dwyer, 2007). Reliability of instruments is also an important consideration to ensure that the evaluation measure is consistent in the kind of data it gathers and helps investigate the aspects of a program in a stable manner when repeatedly administered (Coggshall, 2007). In particular, internal consistency reliability measures if multiple survey items are intended to measure the same property, using the correlation matrix of different items. Cronbach's alpha is the measure used for establishing the internal consistency reliability. A Cronbach's alpha of 0.7 or greater is indicative of a high internal consistency of the instrument for the purpose of establishing the reliability of the research tool (George \& Mallery, 2003).

Researchers have argued for the need of creating a transparent framework in the institutions of higher education that would gather and disseminate evidence about teacher education candidates' learning as well as candidates' feedback on their program's effectiveness (Millet, Payne, Dwyer, Stickler, \& Alexiou, 2008). Considering the salience of the conceptual framework and its learning outcomes in guiding the design and implementation of the teacher education programs in our college of education, the authors developed a survey instrument which was based exactly on the language of the ten learning outcomes of the conceptual framework. Studying the validity and reliability of the learning outcomes was an important goal for us before establishing the survey instrument as the data collection instrument for the unit of teacher education. Research questions guiding this inquiry were:

1. Was the survey instrument based on the ten learning outcomes of the conceptual framework a valid and reliable measure?

2. How did the candidates' ratings on their preparation compare on the ten learning outcomes of the conceptual framework?

3. Were the candidates' ratings affected by their progress in the program or by the type of teacher education program they were pursuing?

\section{Method}

\subsection{Participants}

Since the purpose of the study was to understand the effectiveness of teacher preparation from the perspective of our candidates, the sample for this study included candidates enrolled in teacher education programs at the institution. This professional education unit offered teacher preparation in the following areas: early childhood education (ECE), middle and secondary education (M/S), special education (SpEd), health and physical education (HPE), and art/music/ foreign languages (A/M/F). Programs were at varying levels including: initial teacher certification, advanced preparation, and endorsements. To gather their candidates' perspectives, the teacher education unit sent out an electronic survey titled, “Student Assessment of Program Preparation" to 3380 candidates in two academic years. The candidates identified to receive the email were either at the mid-point in their programs or close to the end. Each semester, the survey email requested anonymous participation from the participants and was followed up by two reminder emails.

In the first year (2010-2011), a total of 368 candidates responded to the survey $(19.7 \%)$, out of which 130 were at the mid-point in their preparation and 238 were at the end point of their program. Among them, 54 were pursuing advanced degree programs and 313 were enrolled in initial teacher preparation. None of the candidates enrolled in programs leading to endorsement responded to this survey. In the second year (2011-2012), a total of 257 candidates responded to the survey (approximately 18\%). Table 2 provides the affiliation of the respondents with the different types of teacher preparation programs offered by this institution.

Table 2. Program Affiliation of Survey Respondents

\begin{tabular}{|c|c|c|c|c|c|}
\hline \multirow{3}{*}{ Number of Respondents } & \multicolumn{5}{|c|}{ Program } \\
\cline { 2 - 6 } & Art/ Music/ Foreign lang. (P-12) & Early Child Ed. & Special Ed. (P-12) & Health Ed. (P-12) & Middle/ Secondary Ed. \\
\cline { 2 - 6 } & 12 & 76 & 51 & 4 & 114 \\
\hline
\end{tabular}

Given the middle/secondary education programs and the early childhood education programs had the largest enrollment of candidates, the most survey responses came from these two program groups as compared to the other smaller programs. For the purposes of analysis, the responses from candidates in the program groups that focused on pre-kindergarten through grade 12 education (special education, health and physical education, and 
art/music/ foreign languages) were categorized together within a group called P-12. For the analysis in this study, therefore, programs were compared using the three categories: early childhood education (ECE), middle and secondary education (M/S), and P-12. Grouping respondents in these ways resulted in three equivalent subsets out of the total sample and enabled more effective comparisons across program types.

\subsection{Research Design}

\subsubsection{Survey Instrument}

The survey used in this study was created on a web portal and the link was emailed to all candidates identified as being at mid or end points of their teacher preparation. The survey sought anonymous feedback from the candidates by asking them to indicate the effectiveness of their program in helping them master the ten learning outcomes of the conceptual framework. Candidates rated their program effectiveness on a five point scale. The questions on the survey were based on the language used by the teacher preparation unit to define the learning outcomes of the conceptual framework (refer to Table 1). For example, the question that related to the first learning outcome asked candidates' opinion of the following statement, "My program has prepared me to use knowledge of child, adolescent, and adult development and theories of learning to design meaningful educational opportunities for all learners." The construct validity of the survey instrument was established using the responses of candidates from 2010-2011. Exploratory factor analysis (EFA) was conducted to identify the number of factors the ten learning outcomes loaded within. Internal consistency reliability of the instrument was tested using the correlation matrix of 10 conceptual framework learning outcomes. We used the criteria of Cronbach's alpha for establishing the internal consistency reliability: Excellent $(\alpha>0.9)$, Good $(0.7<\alpha<0.9)$, Acceptable $(0.6<\alpha<0.7)$, Poor $(0.5<\alpha<0.6)$, Unacceptable $(\alpha<0.5)$ (Kline, 2000; George \& Mallery, 2003).

\subsubsection{Candidate Perceptions of Program Effectiveness}

For investigating the candidates' perspectives of their program's effectiveness in emphasizing the conceptual framework's learning outcomes, a 3-way analysis of variance (ANOVA) was conducted, using the 257 responses from our candidates from 2011-2012. The independent variables in this analysis were: (a) the conceptual framework's ten learning outcomes, (b) program affiliation (ECE, M/S, P-12), and (c) point in preparation (mid or end). Candidate ratings on conceptual framework outcomes served as the dependent variable. The responses on the five point scale were coded as follows: unsure (coded 0), no (coded 1), emerging (coded 2), developing (coded 3), and strength (coded 4). Thus, 4 was the highest rating that could be accorded to any of the learning outcomes.

\section{Results}

Using the 368 responses from our candidates from 2010-2011, exploratory factor analysis (EFA) was conducted to identify the number of factors in the model for best fit. As shown in Figure 1 and Table 3, single factor solution was deemed optimal for the sample of this study $\left(\chi^{2}(35)=201.98 ; \quad \mathrm{RMSEA}=0.09 ; \quad \mathrm{CFI}=0.97\right.$; TLI=0.97), which was well within the accepted range (>.30) of factor loadings for the items on the survey (Costello \& Osbourn, 2005). Thus, validity analyses confirmed that the survey items were coherent and were well constructed. Additionally, the ratings on the ten conceptual framework outcomes showed that the ratings were highly correlated and that the respondents tended to give similar ratings to all of the learning outcomes. The internal consistency of scale was high (Cronbach's alpha $=0.93$ ) and the item total correlations were substantial for all items (range: 0.46-0.74) (refer Table 4). Thus, the survey instrument constructed on the learning outcomes of the conceptual framework was a valid and internally consistent tool for assessing candidates' perspectives of program effectiveness.

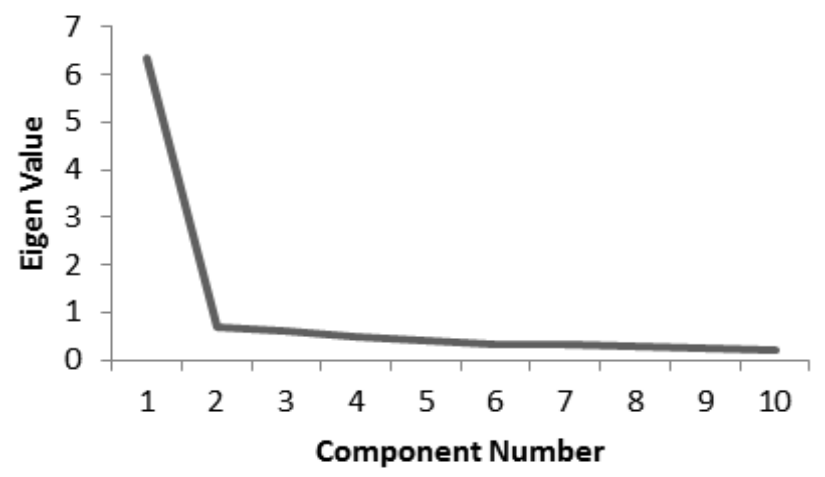

Figure 1. Scree plot indicating dominant factors

Table 3. Standardized Factor Loadings of EFA

Conceptual Framework Learning Outcomes

Our candidates use their knowledge of child, adolescent, and adult development and theories of learning to design meaningful educational opportunities for all learners. (1)

Our candidates possess and use research-based, disciplinespecific knowledge and pedagogy to facilitate learning for all. (2)

Our candidates reflect critically upon data as part of a \begin{tabular}{l|l} 
recursive process when planning, implementing and assessing & 0.848
\end{tabular} teaching, learning, and development. (3)

Our candidates critically analyze educational policies and/or practices that affect learners in metropolitan contexts. (4)

Our candidates know and respect individual differences, establish productive and ethical relationships with candidates, and modify the learning environment to positively impact student learning. (5)

Our candidates create engaging learning communities where the diverse perspectives, opinions, and beliefs of others are acknowledged and respected. (6)

Our candidates commit to continuing personal and professional development.(7)

Our candidates use knowledge of students' cultures, experiences, and communities to create and sustain culturally responsive classrooms and schools. (8)

Our candidates coordinate time, space, activities, technology $\begin{array}{llll}\text { and other resources to provide active and equitable } & 0.812\end{array}$ engagement of diverse learners in real world experiences. (9)

Our candidates implement appropriate communication techniques to provide for learner interaction within local and $\quad 0.734$ global communities. (10) 
Table 4. Inter-Correlation Matrix of Ten Conceptual Framework Learning Outcome

\begin{tabular}{|c|c|c|c|c|c|c|c|c|c|c|}
\hline $\begin{array}{c}\text { Learning } \\
\text { outcome }\end{array}$ & 1 & 2 & 3 & 4 & 5 & 6 & 7 & 8 & 9 & 10 \\
\hline 1 & 1.0 & & & & & & & & & \\
\hline 2 & 0.7 & 1.0 & & & & & & & & \\
\hline 3 & 0.6 & 0.7 & 1.0 & & & & & & & \\
\hline 4 & 0.6 & 0.6 & 0.6 & 1.0 & & & & & & \\
\hline 5 & 0.6 & 0.6 & 0.7 & 0.5 & 1.0 & & & & & \\
\hline 6 & 0.6 & 0.6 & 0.6 & 0.5 & 0.8 & 1.0 & & & & \\
\hline 7 & 0.5 & 0.5 & 0.7 & 0.5 & 0.6 & 0.6 & 1.0 & & & \\
\hline 8 & 0.6 & 0.6 & 0.6 & 0.6 & 0.7 & 0.7 & 0.6 & 1.0 & & \\
\hline 9 & 0.7 & 0.6 & 0.7 & 0.5 & 0.6 & 0.6 & 0.7 & 0.6 & 1.0 & \\
\hline 10 & 0.6 & 0.5 & 0.6 & 0.5 & 0.5 & 0.5 & 0.6 & 0.5 & 0.7 & 1.0 \\
\hline
\end{tabular}

The 3-way ANOVA showed statistical significance for three main effects and one interaction effect (refer Table 5). The main effect for the conceptual framework's learning outcomes indicated that at least one of means was significantly different from the rest of the means $(F(9$, 247)=9.03, $p=.000)$. Other two main effects were program affiliation and time point in the program; yielded $F$ ratios of $F(2,247)=101.15, p=.000$ and $F(1,247)=185.89$, $\mathrm{p}=.000$, respectively. In addition, a significant interaction effect between program affiliation and time point showed that the increase in ratings from the mid to end point differed for the three programs $(\mathrm{F}(2,247)=8.60, \mathrm{p}=.001)$.

Table 5. Main Effects and Interaction Effects on 3-Way ANOVA

\begin{tabular}{|c|c|c|c|c|}
\hline Source & df & MS & F & p \\
\hline Learning outcome & 9 & 6.23 & 9.03 & 0.000 \\
\hline Program & 2 & 69.74 & 101.15 & 0.000 \\
\hline Time & 1 & 128.18 & 185.89 & 0.000 \\
\hline Program*Time & 9 & 5.93 & 8.60 & 0.000 \\
\hline
\end{tabular}

Note. ANOVA=Analysis of Variance, Rating was done on a five point scale.

\subsection{Candidates' Perceptions on Varying Effectiveness of Programs in Emphasizing the Learning Outcomes}

Overall participants rated their teacher preparation programs to be relatively effective at addressing all learning outcomes with means ranging from a low of 2.97 ("developing") to 3.50 (approaching "strength") on the four point scale. The means and standard deviations for each outcome are listed in Table 6.

Table 6. Mean and S.D. of Ten Conceptual Learning Outcome

\begin{tabular}{|c|c|c|}
\hline Learning Outcome & $\mathrm{M}$ & $\mathrm{SD}$ \\
\hline 1 & 3.101 & 0.058 \\
\hline 2 & 3.132 & 0.057 \\
\hline 3 & 3.298 & 0.058 \\
\hline 4 & 2.976 & 0.058 \\
\hline 5 & 3.496 & 0.058 \\
\hline 6 & 3.350 & 0.058 \\
\hline 7 & 3.335 & 0.057 \\
\hline 8 & 3.328 & 0.058 \\
\hline 9 & 3.138 & 0.057 \\
\hline 10 & 2.980 & 0.057 \\
\hline
\end{tabular}

To further investigate the significant differences among the ratings provided by candidates on the ten learning outcomes, Tukey's post-hoc comparisons were conducted. The comparisons categorized the ten mean ratings into four homogeneous subsets: Question 5; Questions 6, 7, and 8; Questions 1, 2, 3, and 9; and Questions 4 and 10 (refer Figure 2).

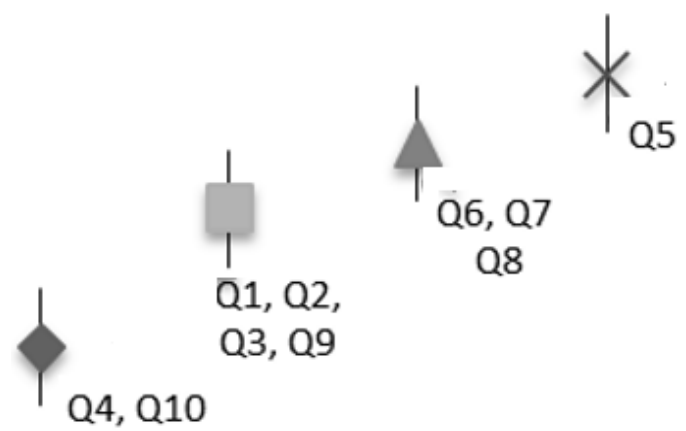

Figure 2. Four Homogeneous groups of rank ordered learning outcomes

Note. Means separated by lines on the graph above are significantly different.

Participants rated question 5, “My program has prepared me to know and respect individual differences, establish productive and ethical relationships with students, and modify the learning environment to positively impact student learning," as the learning outcome on which they felt their program was most effective at addressing. A follow-up post hoc test for significance showed that the mean of ratings on outcome 5 $(\mathrm{M}=3.50$, $\mathrm{SD}=.06)$ was significantly higher than the ratings on all other outcomes.

The next highest ratings were given on questions 6,7 , and 8. Candidates' ratings on these outcomes were in the mean range of 3.33 and 3.35. Questions 6 asked about candidates' ability to create engaging learning communities for all students, question 7 focused on the commitment to continuing personal and professional development, and question 8 asked if candidates' program had prepared them to create and sustain culturally responsive classrooms.

Questions 1, 2, 3, and 9 received the next level of ratings (means between 3.10 and 3.30). These questions asked if the programs at this college had prepared them to use their knowledge of human development, content area, and pedagogy in the classrooms to engage diverse learners.

Ratings were lowest for questions 4 and 10 (means of 2.98s). Question 4 asked about candidates' preparation to critically analyze educational policies and question 10 asked whether the candidates were prepared to facilitate learner interaction with local and global communities.

\subsection{Participants' Impressions of Program Effectiveness as They Matriculate in Their Specific Program}

The results also showed that the interaction between program affiliation (ECE, M/S, P-12) and time point (middle, end) was statistically significant, indicating that the increase in candidates' ratings from mid to the end point was different for the three programs. A post-hoc test of interaction was conducted using a pair-wise comparison of programs at each time point. As shown in Table 7, candidates' ratings from all three programs showed an 
increase from mid to end point. Candidates in the middle/secondary programs rated their programs lower overall in terms of effectiveness at addressing learning outcomes at both the middle and end of their programs. Candidates who were at the midpoint of ECE and P-12 programs rated their programs similarly; but candidates' ratings at the end of their program were significantly higher in the ECE program groups as compared to the P12 program groups. Figure 3 illustrates the interaction effects.

Table 7. Mid and End Point Ratings for the Three Program Groups

\begin{tabular}{|c|c|c|c|}
\hline \multirow{2}{*}{ Ratings } & M/S & ECE & P-12 \\
\cline { 2 - 4 } & $M(S D)$ & $M(S D)$ & $M(S D)$ \\
\hline Mid & $2.65(0.05)$ & $3.36(0.05)$ & $2.88(0.06)$ \\
\hline End & $3.18(0.03)$ & $3.66(0.04)$ & $3.55(0.04)$ \\
\hline$N$ & 114 & 76 & 67 \\
\hline
\end{tabular}

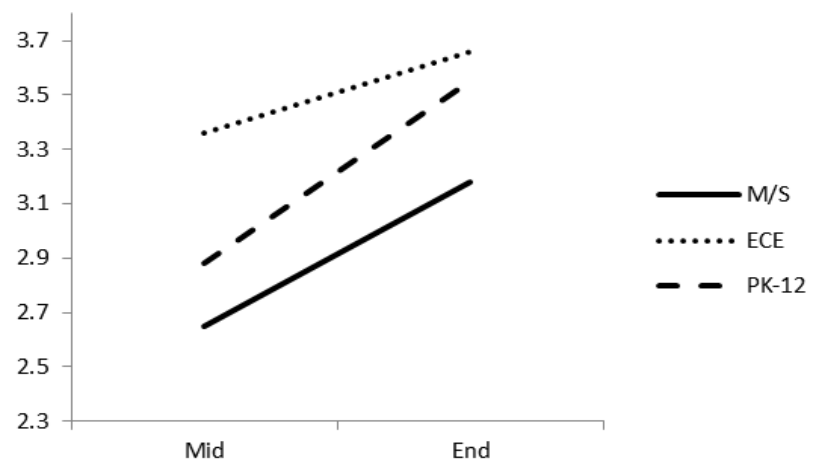

Figure 3. Interaction effect between program group and time point

Although, the ECE candidates gave their program the highest ratings at the midpoint, the increase in their ratings from mid to end point, was the smallest (mean difference=.30). The middle/secondary candidates' midpoint program ratings were the lowest, but showed larger increases from mid to end point as compared to the ECE candidates (mean difference=.53). The P-12 candidates rated their programs higher than middle/secondary programs and their ratings showed the largest increase from midpoint to endpoint (mean difference=.67).

\section{Conclusion}

This study investigated if the teacher education unit in one urban university had moved beyond the basic compliance of listing the conceptual framework's learning outcomes within course syllabi (Diez, 2010). Recent changes in national accreditation procedures have been motivated by the recognition of the need for teacher education institutions to be involved in continuous improvement (Cibulka, 2009). This move was indicative of the desire to move from documenting elements of program and curricular design associated with quality to creating a culture of inquiry which focuses on data-based decision making linking improvements to increasing candidate effectiveness. Since the conceptual framework undergirds teacher preparation at this college, this research sought to understand if there existed coherence in the content knowledge courses, practica, and field experiences around the central ideas of the conceptual framework, as perceived by the candidates. This self-study also endeavored to identify the areas that came across as strengths to the candidates in our preparation programs and the aspects that needed improvement. Although the conceptual framework's learning outcomes were already assessed at different transitions points in the program through key assessments, this study analyzed the unique perspective of the teacher candidates on how apparent these standards became to them in course work and field experiences.

Since our survey was constructed on the ten learning outcomes of the conceptual framework, the validity and reliability analysis provided us important feedback about the alignment of these outcomes with teaching for social justice and equity. All of the learning outcomes loaded together in a single factor solution indicating that the college's conceptual framework was comprised of outcomes that were interconnected. In other words, mastery of one aspect of this social justice framework would be linked to the mastery of the other learning outcomes. Since the survey instrument had a high internal consistency, this was a promising tool for the college to conduct self-evaluation research, collect large scale data across the different teacher education programs in unit, and develop a transparent and efficient method to collect feedback on program effectiveness. Such data would be beneficial for all stakeholders including: faculty, administrators, future candidates, policy makers, accrediting agencies, and the community at large.

Based on the ratings provided by our teacher candidates on the survey, we could conclude that overall, they felt well prepared to be informed, empowered and engaged in the lives of their future students. The average means for all learning outcomes were high and increased from the midpoint to the end, indicating as they moved through the program, their sense of preparedness to teach for social justice and equity increased. This finding indicated that the teacher education unit had been successful in emphasizing a common vision among its numerous and diverse teacher education programs. However, the results also showed that across programs a set of learning outcomes were not as clearly emphasized. The learning outcome 4 which related to the candidates' preparation to be able to critically analyze educational policies and practices that affect learners in metropolitan contexts was consistently ranked the lowest at the midpoint and endpoint by candidates from across programs and years. Since the unit considers this knowledge vital for candidates success in urban schools, low ratings on outcome 4 are indicative of a need to bolster emphasis on educational policies and practices within course work and field placements. Studies have shown that beginning teachers may be more vested in and spend more time mastering the immediate aspects of classroom management and instruction, and may be less concerned with becoming agents of social change (Fieman-Nemser, 2012). In our case too, the high ratings on outcome 5 and 6 which dealt with creating engaging learning communities and reaching out to the individual needs of the children, showcased that the candidates felt most confident about their preparation in these two aspects of learning to teach for social justice. However, teacher education programs can be designed to help the candidates 
develop a critical lens towards district curriculum, policies, and the alternatives that exist for them to feel better prepared in becoming socially just and equitable in their instruction (Agarwal, Epstein, Oppenheim, Oyler, \& Sonu, 2010).

Additionally, programs in ECE and P-12 were perceived as better aligned with the unit's vision and conceptual framework, receiving higher mid and endpoint ratings as compared to the $\mathrm{M} / \mathrm{S}$ program. Previous program evaluation research examining the preparation of teachers for urban schools has indicated universities are often at different points in addressing issues of cultural and linguistic diversity (Hollins \& Guzman, 2005). Our study indicates there different programs within universities might also be at different points in emphasizing the mission of the institution, thereby impacting the perception of the candidates about their ability to be effective educators in the urban context. This is critical feedback for the faculty in these programs and calls for re-examining the design and delivery of these programs to make them better aligned with the conceptual framework.

In conclusion, this study contributes to genre of selfstudies in teacher education, a field typically informed by qualitative methodology, by underscoring the value of using of quantitative methodologies to collect large-scale data, incorporating instruments that are reliable and valid, as an investigative tool that can inform teacher preparation programs (Cochran-Smith et al, 2009). Using rigor in our methodology increases the credibility of self-study research and at the same time provides us with invaluable feedback that is important not just for policy and accreditation purposes but also for practice and continuous improvement of teacher education.

\section{Statement of Competing Interests}

The authors have no competing interests.

\section{References}

[1] Agarwal, R., Epstein, S., Oppenheim, R., Oyler, C., \& Sonu, D. (2010). From ideal to practice and back again: Beginning teachers teaching for social justice. Journal of Teacher Education, 61(3), 237-247.

[2] Berry, A. (2004). A self-study in teaching about teaching. In. J. Loughran, M.L. Hamilton, V.K. LaBoskey, \& T. Russell (Eds.) International handbook of self-study of teaching and teacher education practice (pp. 1295-1332). Dordrecht, The Netherlands: Kluwer.

[3] Bhatnagar, R. (2011). Use of standards in assessment of student teachers: Purposes fulfilled, untapped potentials. Paper presented at the annual meeting of the American Education Research Association, New Orleans, LA.

[4] Boyles, D. (2009). Considering Lorraine Code's ecological thinking and standpoint epistemology: A theory of knowledge for agentic knowing in schools? Philosophical Studies in Education, 40, 125-137.

[5] Bronfenbrenner, U. (1986). Ecology of the family as a context for human development: Research perspectives. Developmental Psychology, 22, 723-742.

[6] Cibulka, J. G. (2009). Improving relevance, evidence, and performance in teacher preparation. Education Digest: Essential Readings Condensed for Quick Review, 75(2), 44-49.

[7] Cochran-Smith, M. (2004). Walking the road: Race, diversity and social justice in teacher education. New York: Teachers College Press.
[8] Cochran-Smith, M., \& Boston College Evidence Team (2009). "Re-culturing teacher education: Inquiry, evidence, and action. Journal of Teacher Education, 60, 458-468.

[9] Coggshall, J. G. (2007). Communication framework for measuring teacher quality and effectiveness: Bringing coherence to the conversation. Washington, DC: National Comprehensive Center for Teacher Quality. Retrieved from

www.http://www.tqsource.org/communicationFramework.phpww w.

[10] Council of Chief State School Officers. (2013, April). Interstate teacher assessment and support consortium InTASC Model core teaching standards and learning progressions for teachers 1.0: A resource for ongoing teacher development. Washington, DC: Author.

[11] Creswell, J. W., Plano Clark, V. L., Gutmann, M. L., \& Hanson,W. E. (2003). Advance mixed methods research designs. In A.Tashakkori \& C. Teddlie (Eds.), Handbook of mixed methods in social and behavioral research (pp. 209-240). Thousand Oaks, CA: Sage.

[12] Darling-Hammond, L., \& Bransford, J. (2005). Preparing teachers for a changing world: What teachers should learn and be able to do. San Francisco: Jossey-Bass.

[13] Delandshere, G., \& Arens, S. A. (2003). Examining the quality of the evidence in preservice portfolios. Journal of Teacher Education, 54, 57-73.

[14] Delandshere, G. \& Petrosky, A. (2004). Political rationales and ideological stances of the standards-based reform of teacher education in the U.S. Teaching and Teacher Education, 20, 1-15.

[15] Delpit, L. (1995). Other people's children: Cultural conflict in the classroom. New York: New Press.

[16] Dewey, J. (1938). How we think: A restatement of the relation of reflective thinking to the educative process. Boston: D. C. Heath \& Co.

[17] Diez, M. E. (2010). It is complicated: Unpacking the flow of teacher education's impact on student learning. Journal of Teacher Education, 61, 441-450.

[18] Dooley, C. M., \& Assaf, L. C. (2009). Contexts matter: Two teachers' language arts instruction in this high-stakes era. Journal of Literacy Research, 41, 354-391.

[19] Fairbanks, C. M., Duffy, G. G., Faircloth, B. S., He, Y., Levin, B., Rohr, J., \& Stein, C. (2010). Beyond knowledge:

[20] Exploring why some teachers are more thoughtfully adaptive than others. Journal of Teacher Education, 61, 161-171.

[21] Feimen-Nemser, S. (2001). Helping novices learn to teach: lessons from an exemplary support teacher. Journal of Teacher Education, 52, 17-30.

[22] Feiman-Nemser, S. (2012). Teachers as learners. Harvard Educational Press: Cambridge, MA.

[23] Gay, G. (2010). Acting on beliefs in teacher education for cultural diversity. Journal of Teacher Education, 61,143-152.

[24] Goe, L., Bell, C., \& Little, O. (2008). Approaches to evaluating teacher effectiveness: A research synthesis. Washington D.C.: National Comprehensive Center for Teacher Quality.

[25] Goodlad, J. (2008). Advancing the public purpose of schooling in teacher education. In M.Cochran-Smith, S. Feiman-Nemser, D. J. McIntyre, and K. E. Demers (Eds.) Handbook of research on teacher education: Enduring questions in changing contexts $\left(3^{\text {rd }}\right.$ ed.), pp. 111- 116. New York: Routledge.

[26] George, D., \& Mallery, P. (2003). SPSS for Windows step by step: A simple guide and reference 11.0 update $\left(4^{\text {th }}\right.$ ed.). Boston: Allyn \& Bacon

[27] Grossman, P., Hammerness, K. M., McDonald, M., \& Ronfeldt, M. (2008). Constructing coherence: Structural predictors of perceptions of coherence in NYC teacher education programs. Journal of Teacher Education, 59, 273-287.

[28] Hammerness, K. (2006). From coherence in theory to coherence in practice. Teachers College Record, 108, 1241-1265.

[29] Hollins, E., \& Guzman, M. T., (2005). Research on preparing teachers for diverse populations. In M. Cochran-Smith and K. Zeichner (Eds.), Studying teacher education: The report of the AERA panel on research and teacher education (pp. 477-548). Mahwah, NJ: Lawrence Erlbaum Publishers.

[30] King, E. J. (2000). White teachers at the crossroads: A moral choice for White teachers. Teaching Tolerance Magazine, 2000, 14-15.

[31] King, E.J. (2006). On dysconciousness: An interview with Joyce E. King. Educational Studies, 40(2), 197-208. 
[32] King, P. M., \& Kitchener, K.S. (2004). Reflective judgment: Theory and research on the development of epistemic assumptions through adulthood. Educational Psychologist, 39, 5-18.

[33] Kline, p. (2000). The handbook of psychological testing ( $2^{\text {nd }}$ ed.). pp.13. London:Routledge

[34] Kozol, J. (2005). The shame of the nation: The restoration of apartheid schooling in America. New York: Crown Publishing.

[35] Knapp, M.Copland, M. \& Swinnerton, J. (2007). Understanding the promise and dynamics of data informed leadership. In P. Moss (Ed.) Evidence and decision making, 106 ${ }^{\text {th }}$ yearbook of the National Society for the Study of Education. (Pt. 1, pp. 74-104). Chicago: National Society for the Study of Education.

[36] Koerner, M., Rust, F. O., \& Baumgartner, F. (2002). Exploring roles in student teaching placements. Teacher Education Quarterly, 29, 35-58.

[37] Korthagen, J., Loughran, J., \& Russell, T. (2006). Developing fundamental principles for teacher education programs and practices, Teaching and Teacher Education, 22, 1020-1041.

[38] Kornfeld, J., Grady, K., Marker, P., \& Ruddell, M. (2007). Caught in the current: A self-study of state-mandated compliance in a teacher education program. Teachers College Record, 109 (8), 1902-1930.

[39] LaBoskey, V.K., \& Richert, A. E. (2002). Identifying good student teaching placements: A programmatic perspective. Teacher Education Quarterly, 29, 7-34.

[40] Landow, G.P. (2006). Hypertext 3.0. Baltimore: The Johns Hopkins University Press.

[41] Lieberman, A., \& Pointer Mace, D. (2011). Making practice public: Teacher learning in the $21^{\text {st }}$ century. Journal of Teacher Education, 61, 77-88.

[42] Loughran, J. (2006) Developing a pedagogy of teacher education Understanding teaching and learning about teaching. Routledge: London.

[43] Louis, K. S. (2008). Creating and sustaining professional communities. In A. Blankstein, P. Houston, \& R. Cole (Eds.), Sustaining professional learning communities (pp. 41-47). Thousand Oaks, CA:Corwin.

[44] Millet, C.M., Stickler, L.M., Payne, D.G., \& Dwyer, C.A. (2007). A culture of evidence: Critical features of assessments for postsecondary learning. Washington, DC: National Comprehensive Center for Teacher Quality. Retrieved from https://www.ets.org/Media/Resources_For/Higher_Education/pdf/ 4418_COEII.pdf.
[45] Milner, H. R. (2010). What does teacher education have to do with teaching? Implications for diversity studies. Journal of Teacher Education, 61, 118-131.

[46] Noddings, N. (2002). The caring teacher. In V. Richardson (Ed.), Handbook of research on teaching (pp. 99-105). Washington, DC: American Educational Research Association.

[47] Peck, C. A., Galluchi, C., \& Sloan, T. (2010). Negotiating implementation of high-stakes performance assessment policies in teacher education: From compliance to inquiry. Journal of Teacher Education, 61, 451-463.

[48] Plecki, M. L., Elfers A. M., \& Nakamura, Y. (2012). Using evidence for teacher education program improvement and accountability: An illustrative case of the role of value-added measures. Journal of Teacher Education, 63, 318-334.

[49] Pianta, R. C. (1998). Enhancing relationships between teachers and children. Washington, DC: American Psychological Association.

[50] National Council for Accreditation of Teacher Education. (2008). Professional standards for the accreditation of teacher preparation institutions. Washington, DC: NCATE.

[51] National Council for Accreditation of Teacher Education. (2010).Transforming teacher education through clinical practice: A national strategy to prepare effective teachers. Washington, DC: NCATE.

[52] United States Department of Education. (2002). No Child Left Behind Act of 2001, pub. L. No. 107-110, 115 stat. 1425. Washington, DC: U.S. Department of Education.

[53] Vygotsky, L. S. (1978). Mind in society: The development of higher psychological processes. Cambridge: Harvard University Press. (Original works published 1930, 1933, and 1935).

[54] Wilson, S. M., Floden, R., \&Ferrini-Mundy, J. (2001). Teacher preparation research: Content knowledge, gaps, and recommendations: A research report prepared for the U.S. Department of Education. Seattle, WA: Center for the Study of Teaching and Policy.

[55] Wysocki, A.F. (2004). Opening new media to writing: Openings \& justifications. In A.F. Wysocki, J. Johnson-Eilola, C.L. Selfe, \& G. Sirc (Eds.), Writing new media: Theory and applications for expanding the teaching of composition (1-33). Logan, UT: Utah StateUniversity Press.

[56] Zeichner, K. M. (2005). A research agenda for teacher education. In M. Cochran-Smith and K. M. Zeichner's (Eds.), Studying teacher education: The report of the AERA plan on research and teacher education (pp. 761-766). Lawrence Erlbaum Associates: Mahwah, NJ. 